\title{
Soil Nutrient Status, NPK Uptake and Viable Bacterial Count as Influenced by Different Organic Nutrient Sources in European Carrot
}

\author{
Nitika*, Kuldeep Singh Thakur and Devinder Kumar Mehta
}

Department of Vegetable Science, Dr YS Parmar University of Horticulture and Forestry, Nauni, Solan (HP)-173230, India

*Corresponding author

\section{A B S T R A C T}

\begin{tabular}{|l|}
\hline Ke y w o r d s \\
Vermicompost, \\
$\begin{array}{l}\text { Jeevamrut, } \\
\text { Panchgavya, Available } \\
\text { NPK, NPK uptake }\end{array}$ \\
\hline Article Info \\
\hline $\begin{array}{l}\text { Accepted: } \\
\text { 12 July } 2018 \\
\text { Available Online: } \\
\text { 10 August } 2018\end{array}$ \\
\hline
\end{tabular}

Keywords

Vermicompost Panchgavya, Available

Article Info

Accepted: Available Online: 10 August 2018
A study was undertaken to assess the effect of organic nutrient sources on soil nutrient status, NPK uptake and viable bacterial count in European carrot. The experiment was conducted at Organic Block of Experimental Farm, Department of Vegetable Science, Dr YS Parmar University of Horticulture and Forestry, Nauni, Solan, (HP) in the Rabi season of 2017. The experiment was laid out in Randomized Complete Block Design (RCBD) Factorial with sixteen treatments in three replication. Treatments comprised combination of four levels of organic manure and organic liquid formulations. The results revealed that combined application of vermicompost 5 t/ha + Jeevamrit - drenching @ $5 \%+$ Panchgavya - spray @ 3\% exhibited significant higher values for soil nutrient status and NPK uptake. Highest viable bacterial count was also obtained under this treatment. Therefore, vermicompost along with Jeevamrit and Panchgavya can be recommended for sustainable production of carrot and to nourish soil fertility under mid-hills condition of Himachal Pradesh.

\section{Introduction}

Carrot (Daucus carota L.) belongs to family Umbelliferae and is an important root vegetable grown throughout the world. It is grown during spring, summer and autumn in temperate regions and during winter in tropical and subtropical climates. In India, it is grown in almost all parts of the country, both in plains and as well as in hills. It is native to Afganistan (Rubatzky and Yamaguchi, 1999). It is used as salad and cooked vegetable. Carrot in combination with other vegetables can produce especially healthful, tasty and refreshing drinks. Carrot contains appreciable amount of carotene, thiamine, protein, calcium and riboflavin. It can play an important role to protect the night blindness in children providing vitamin-A. Being an antioxidant, a combination of carrot and orange juice also reduces the oxidation of low-density lipoproteins in habitual cigarette smokers (Abbey et al., 1995). Maintenance of soil fertility is a prerequisite for long term sustainable agriculture. Modern conventional farming uses chemical fertilizers to stimulate crop production resulting in decline in soil structure and soil aggregation, decrease in water infilteration and an increase in soil salinity and soil bulk density. Moreover, the 
use of inorganic fertilizers has been associated with human health problems and environment degradation (Arisha and Bardisi, 1999). Organic manures supply the required nutrients, improve soil structure, increase microbial population and at the same time maintain the quality of crop produce (Wong et al., 1999, Nehra et al., 2001 and Suresh et al., 2004).

Organic manure can serve as a substitute to mineral fertilizers (Naeem et al., 2006). Several authors have reported the importance of organic manure as a source of nutrients and a means of soil rejuvination (Adeleye et al., 2010). Considering the above facts the present study was undertaken to investigate the potential use of organic nutrient sources on soil nutrient status, NPK uptake and viable bacterial count in carrot.

\section{Materials and Methods}

The investigation was carried out at Experimental Farm of the Department of Vegetable Science, Dr YS Parmar University of Horticulture and Forestry, Nauni, Solan (HP) during Rabi season (September December) of 2017. The experimental site is located at an altitude of 1270 meters above mean sea level lying between latitude of $30^{\circ} 54^{\prime}$ 'North and longitude of $77^{\circ} 5^{\prime}$ ' East and falls under mid hill zone of Himachal Pradesh.

The layout of experimental field was laid down in Randomized Complete Block Design (RCBD) Factorial with three replications comprising of sixteen treatment combinations of two factors - Factor I: organic manure (M) and Factor II: organic liquid formulations (L). The details of treatments combination is given in Table 1. Seeds of carrot cv. Early Nantes were sown in the raised plots of size $2.25 \mathrm{~m}^{2}$ on $15^{\text {th }}$ September, 2017. Seeds were sown in lines at a row spacing of $30 \mathrm{~cm}$ and later on thinned to $10 \mathrm{~cm}$ spacing between the plants, thus accommodating 75 plants per plot. The organic manures (vermicompost and well rotten farm yard manure) were applied at the time of land preparation. Jeevamrit 5 per cent (as soil drench) and Panchgavya @ 3 per cent (as foliar spray) were applied at 20, 40, 60 days and 30, 50, 70 days after sowing of seeds respectively. The observations were recorded on available NPK content in soil ( $\mathrm{kg} / \mathrm{ha})$ (before and after termination of experiment), viable bacterial count (cfu/g) and NPK uptake by plant $(\mathrm{kg} / \mathrm{ha})$. The observed data were statistically analyzed and the treatments were tested at 5 per cent level of significance as per procedure described by (Panse and Sukhatme, 2000) under the Randomized Complete Block Design (RCBD) Factorial. The analysis of the soil was done before planting and it was found that soil was rich in organic matter and having $\mathrm{pH}, \mathrm{EC}$ and OC values of 7.29, $0.43 \mathrm{dSm}^{-1}$ and 1.05 per cent, respectively. The available $\mathrm{N}, \mathrm{P}$ and $\mathrm{K}$ content and viable bacterial count was recorded to be $370.00,43.00$ and 270.92 $\mathrm{kg} / \mathrm{ha}$ and $86.90 \times 10^{5} \mathrm{cfu} / \mathrm{g}$, respectively.

\section{Soil analysis}

Soil samples from $0-15 \mathrm{~cm}$ depth were collected from all the plots separately and were air dried, crushed, passed through $2 \mathrm{~mm}$ sieve and stored in cloth bags for chemical analysis like available NPK. Available N was determined by alkaline potassium permanganate method (Subbiah and Asija, 1956) and available phosphorus was determined by Olsen's method (Olsen et al., 1954) using spectrophotometer. Available potassium was determined by ammonium acetate method using flame photometer (Mervin and Peech, 1951). For estimation of viable bacterial count one gram soil mixture was taken in $9 \mathrm{ml}$ of sterilized water blank and the soil suspension was diluted in 10 fold series. Then, microbial count was determined by spread plate technique on different media as described by (Subba Rao, 1999). 


\section{Plant analysis}

The samples collected were immediately weighed and brought to the laboratory in paper bags. All the samples were washed in series, first with tap water, and then with $0.1 \mathrm{~N}$ $\mathrm{HCl}$ followed by distilled water. The washed samples were allowed to dry in air and subsequently in oven at $60^{\circ} \mathrm{C}$ till constant weight attained.

The dried samples were then grinded in a electric grinder and stored in butter paper bags for chemical analysis. For estimation of N, 1.0 $\mathrm{g}$ of plant material was digested in concentrated $\mathrm{H}_{2} \mathrm{SO}_{4}$ in the presence of a digestion mixture.

After digestion the $\mathrm{N}$ was determined by micro-kjeldahl method. For the estimation of $\mathrm{P}$ and $\mathrm{K}, 1.0 \mathrm{~g}$ of the plant sample was digested in 4:1 nitric acid and per chloric acid $\left(\mathrm{HNO}_{3}: \mathrm{HClO}_{4}\right)$ mixture. In order to have complete transfer of the digestion material, three washings of the digestion flask were given with distilled water and volume was made to $100 \mathrm{ml}$. Potassium in the extract was determined by flamephotometer and $\mathrm{P}$ was determined by Vanado-molybdate yellow colour method (Jackson, 1973).

\section{Results and Discussion}

\section{Available NPK and NPK uptake}

Application of different levels of organic manures, organic liquid formulations and their combinations significantly influenced the available NPK and NPK uptake (Table 2). The application of vermicompost $\left(\mathrm{M}_{2}\right)$ accounted for the maximum available nitrogen (367.94 $\mathrm{kg} / \mathrm{ha}$ ), phosphorous $(59.50 \mathrm{~kg} / \mathrm{ha})$, potassium $(352.09 \mathrm{~kg} / \mathrm{ha})$ and uptake of nitrogen (113.49 $\mathrm{kg} / \mathrm{ha})$, phosphorus (27.98 $\mathrm{kg} / \mathrm{ha})$ and potassium $(108.68 \mathrm{~kg} / \mathrm{ha})$ as compared to control $\mathrm{M}_{0}$. Among the liquid formulations, maximum available nitrogen $(367.52 \mathrm{~kg} / \mathrm{ha})$, phosphorous $(61.98 \mathrm{~kg} / \mathrm{ha})$, potassium $(354.07$ $\mathrm{kg} / \mathrm{ha})$ and uptake of nitrogen $(112.78 \mathrm{~kg} / \mathrm{ha})$, phosphorus $(27.65 \mathrm{~kg} / \mathrm{ha})$ and potassium $(107.02 \mathrm{~kg} / \mathrm{ha})$ were found in $\mathrm{L}_{3}$ and were minimum in $\mathrm{L}_{0}$.

The data on different combination divulged that maximum available nitrogen (387.56 $\mathrm{kg} / \mathrm{ha})$, phosphorus $(71.58 \mathrm{~kg} / \mathrm{ha})$, potassium $(366.90 \mathrm{~kg} / \mathrm{ha})$ and uptake of nitrogen $(127.05$ $\mathrm{kg} / \mathrm{ha})$, phosphorus $(29.84 \mathrm{~kg} / \mathrm{ha})$ and potassium $(120.31 \mathrm{~kg} / \mathrm{ha})$ were observed in $\mathrm{M}_{2} \mathrm{~L}_{3}$ and were minimum in control $\left(\mathrm{M}_{0} \mathrm{~L}_{0}\right)$.

Increase in available $\mathrm{N}$ may be due to slow release of nutrients through organic manure and enriching available pool of nitrogen (Bharadwaj and Omanwar, 1994) or it might be due to the addition of nitrogen through vermicompost, Jeevamrit and Panchgavya and multiplication of soil microbes, which could convert organically bound $\mathrm{N}$ to inorganic form to the available pool of the soil.

The buildup of available $\mathrm{P}$ under these treatments may be due to release of organic acids during microbial decomposition of organic matter which might have helped in solubility of native phosphates thus increases the available phosphorus pool in the soil (Khan et al., 1984).

Increase in available $\mathrm{K}$ could be attributed to the beneficial effect of organic matter in releasing $\mathrm{K}_{2} \mathrm{O}$ due to the interaction of organic matter with clay and direct addition of $\mathrm{K}_{2} \mathrm{O}$ to the available pool of soil. Further the increase in $\mathrm{N}, \mathrm{P}$ and $\mathrm{K}$ uptake might be due to the enhancement of availability of nutrients in the soil (through application of enhancing the availability of nutrients). Similar findings were reported by Sharma et al., (2009), Gore and Sreenivasa (2011), Prativa and Bhattarai (2011), Singh et al., (2014) and Suklabaidya et al., (2017). 
Table.1 Details of treatments

Factor I: Organic manure (M): $\mathrm{M}_{0}-$ No organic manure, $\mathrm{M}_{1}-\mathrm{FYM} @ 10$ t/ha, $\mathrm{M}_{2}$ Vermicompost @ 5 t/ha, M - FYM @ 5 t/ha + Vermicompost @ 2.5 t/ha

Factor II: Organic Liquid Formulation (L): $\mathrm{L}_{0}$ - No organic formulation, $\mathrm{L}_{1}$ - Jeevamrit (drenching@5\%), L2 - Panchgavya (spray @ 3\%), L3 - Jeevamrit + Panchgavya (Drenching @ $5 \%+$ spray@3\%)

\begin{tabular}{|c|c|c|}
\hline $\begin{array}{l}\text { Treatment } \\
\text { No. }\end{array}$ & $\begin{array}{l}\text { Treatment } \\
\text { code }\end{array}$ & Treatments \\
\hline $\mathrm{T}_{1}$ & $\mathrm{M}_{0} \mathrm{~L}_{0}$ & No organic manure + No organic formulations (control) \\
\hline$\overline{T_{2}}$ & $\mathrm{M}_{0} \mathrm{~L}_{1}$ & No organic manure + Jeevamrit (drenching@ $5 \%$ ) \\
\hline $\mathbf{T}_{\mathbf{3}}$ & $\mathrm{M}_{0} \mathrm{~L}_{2}$ & No organic manure + Panchgavya (spray @3\%) \\
\hline$\overline{\mathbf{T}_{4}}$ & $\mathrm{M}_{0} \mathrm{~L}_{3}$ & $\begin{array}{l}\text { No organic manure + Jeevamrit + Panchgavya (drenching @ } 5 \% \\
\text { + spray@3\%) }\end{array}$ \\
\hline $\mathbf{T}_{5}$ & $\mathrm{M}_{1} \mathrm{~L}_{0}$ & FYM@10 t/ha + no organic formulations \\
\hline $\mathrm{T}_{6}$ & $\mathrm{M}_{1} \mathrm{~L}_{1}$ & FYM@10 t/ha + Jeevamrit (drenching@5\%) \\
\hline $\mathbf{T}_{7}$ & $\mathrm{M}_{1} \mathrm{~L}_{2}$ & FYM@10 t/ha +Panchgavya (spray@3\%) \\
\hline$\overline{T_{8}}$ & $\mathrm{M}_{1} \mathrm{~L}_{3}$ & $\begin{array}{l}\text { FYM@10 t/ha + Jeevamrit + Panchgavya (drenching@5\%+ } \\
\text { spray@3\%) }\end{array}$ \\
\hline$T_{9}$ & $\mathrm{M}_{2} \mathrm{~L}_{0}$ & Vermicompost@5 t/ha + no organic formulations \\
\hline $\mathbf{T}_{10}$ & $\mathrm{M}_{2} \mathrm{~L}_{1}$ & Vermicompost@5t/ha +Jeevamrit (drenching@5\%) \\
\hline$\overline{T_{11}}$ & $\mathrm{M}_{2} \mathrm{~L}_{2}$ & Vermicompost@5t/ha+Panchgavya (spray@3\%) \\
\hline$\overline{T_{12}}$ & $\mathrm{M}_{2} \mathrm{~L}_{3}$ & $\begin{array}{l}\text { Vermicompost@5 t/ha+Jeevamrit+Panchgavya (drenching } \\
\text { @5\%+spray@3\%) }\end{array}$ \\
\hline$\overline{T_{13}}$ & $\mathrm{M}_{3} \mathrm{~L}_{0}$ & $\begin{array}{l}\text { FYM@ } 5 \text { t/ha + vermicompost @ } 2.5 \text { t/ha + no organic } \\
\text { formulations }\end{array}$ \\
\hline$T_{14}$ & $\mathrm{M}_{3} \mathrm{~L}_{1}$ & $\begin{array}{l}\text { FYM @ } 5 \text { t/ha + vermicompost @ } 2.5 \text { t/ha + Jeevamrit } \\
\text { (drenching @ } 5 \% \text { ) }\end{array}$ \\
\hline$\overline{T_{15}}$ & $\mathrm{M}_{3} \mathrm{~L}_{2}$ & $\begin{array}{l}\text { FYM@ } 5 \text { t/ha + vermicompost @ } 2.5 \text { t/ha + Panchgavya (spray } \\
\text { @ } 3 \% \text { ) }\end{array}$ \\
\hline $\mathbf{T}_{16}$ & $\mathrm{M}_{3} \mathrm{~L}_{3}$ & $\begin{array}{l}\text { FYM @ 5t/ha + vermicompost @ 2.5 t/ha + Jeevamrit + } \\
\text { Panchgavya (drenching @ } 5 \%+\text { spray @ } 3 \% \text { ) }\end{array}$ \\
\hline
\end{tabular}


Int.J.Curr.Microbiol.App.Sci (2018) 7(8): 1783-1789

Table.2 Effect of organic nutrient sources on available NPK and NPK uptake

\begin{tabular}{|c|c|c|c|c|c|c|}
\hline Particular & $\begin{array}{l}\text { Avail N } \\
\text { in soil } \\
\text { (kg/ha) }\end{array}$ & $\begin{array}{l}\text { Avail P in } \\
\text { soil } \\
\text { (kg/ha) }\end{array}$ & $\begin{array}{l}\text { Avail K } \\
\text { in soil } \\
\text { (kg/ha) }\end{array}$ & $\begin{array}{c}\text { Nitrogen } \\
\text { uptake by } \\
\text { plant (kg/ha) }\end{array}$ & $\begin{array}{c}\text { Phosphorus } \\
\text { uptake by } \\
\text { plant (kg/ha) }\end{array}$ & $\begin{array}{c}\text { Potassium } \\
\text { uptake by } \\
\text { plant } \\
\text { (kg/ha) }\end{array}$ \\
\hline \multicolumn{7}{|c|}{ Organic Manure (M) } \\
\hline $\mathbf{M}_{0}$ & 311.43 & 49.86 & 326.18 & 97.20 & 22.34 & 91.60 \\
\hline $\mathbf{M}_{1}$ & 347.11 & 50.78 & 341.00 & 100.19 & 24.39 & 97.64 \\
\hline $\mathbf{M}_{2}$ & 367.94 & 59.50 & 352.09 & 113.49 & 27.98 & 108.68 \\
\hline $\mathbf{M}_{3}$ & 358.93 & 51.58 & 342.52 & 107.02 & 24.70 & 102.52 \\
\hline $\mathrm{CD}_{0.05}$ & 0.48 & 2.14 & 0.49 & 2.61 & 1.39 & 0.16 \\
\hline \multicolumn{7}{|c|}{$\begin{array}{c}\text { Organic Liquid } \\
\text { Formulations (L) }\end{array}$} \\
\hline $\mathbf{L}_{0}$ & 316.99 & 42.61 & 318.18 & 95.12 & 20.60 & 92.67 \\
\hline $\mathbf{L}_{1}$ & 353.50 & 57.04 & 347.90 & 106.84 & 26.28 & 101.59 \\
\hline $\mathbf{L}_{2}$ & 347.38 & 50.10 & 341.64 & 103.18 & 24.88 & 99.15 \\
\hline$\overline{\mathbf{L}_{3}}$ & 367.52 & 61.98 & 354.07 & 112.78 & 27.65 & 107.02 \\
\hline $\mathrm{CD}_{0.05}$ & 0.48 & 2.14 & 0.49 & 2.61 & 1.39 & 0.16 \\
\hline \multicolumn{7}{|c|}{ Interaction $\mathbf{M} \times \mathbf{L}$} \\
\hline $\mathrm{M}_{0} \mathrm{~L}_{0}$ & 296.89 & 38.53 & 310.88 & 90.58 & 15.05 & 88.17 \\
\hline $\mathbf{M}_{0} \mathbf{L}_{1}$ & 311.16 & 54.89 & 332.19 & 98.04 & 24.99 & 93.50 \\
\hline $\mathrm{M}_{0} \mathrm{~L}_{2}$ & 298.47 & 49.95 & 327.35 & 96.17 & 23.78 & 89.33 \\
\hline $\mathbf{M}_{0} \mathbf{L}_{3}$ & 339.20 & 56.04 & 334.29 & 104.05 & 25.53 & 95.42 \\
\hline $\mathbf{M}_{1} \mathbf{L}_{0}$ & 308.21 & 42.11 & 316.90 & 90.95 & 20.49 & 91.74 \\
\hline $\mathbf{M}_{1} \mathbf{L}_{1}$ & 355.91 & 54.20 & 342.20 & 102.93 & 25.43 & 98.87 \\
\hline $\mathbf{M}_{1} L_{2}$ & 354.36 & 47.97 & 351.07 & 98.94 & 25.12 & 97.39 \\
\hline $\mathbf{M}_{1} \mathbf{L}_{3}$ & 369.97 & 58.84 & 353.84 & 107.93 & 26.53 & 102.55 \\
\hline $\mathbf{M}_{2} \mathbf{L}_{0}$ & 341.23 & 45.79 & 324.34 & 100.64 & 25.25 & 95.67 \\
\hline $\mathbf{M}_{2} \mathbf{L}_{1}$ & 374.91 & 65.44 & 361.75 & 117.20 & 28.93 & 110.03 \\
\hline $\mathbf{M}_{2} \mathbf{L}_{2}$ & 368.07 & 55.22 & 355.40 & 109.09 & 27.89 & 108.72 \\
\hline $\mathbf{M}_{2} \mathbf{L}_{3}$ & 387.56 & 71.58 & 366.90 & 127.05 & 29.84 & 120.31 \\
\hline $\mathbf{M}_{3} \mathbf{L}_{0}$ & 321.67 & 44.02 & 320.58 & 98.30 & 21.64 & 95.12 \\
\hline $\mathbf{M}_{3} \mathbf{L}_{1}$ & 372.04 & 53.59 & 355.49 & 109.18 & 25.76 & 103.99 \\
\hline $\mathbf{M}_{3} \mathbf{L}_{2}$ & 368.64 & 47.27 & 332.75 & 108.51 & 22.75 & 101.17 \\
\hline $\mathbf{M}_{3} \mathbf{L}_{3}$ & 373.34 & 61.44 & 361.27 & 112.07 & 28.68 & 109.80 \\
\hline $\mathrm{CD}_{0.05}$ & 0.97 & 4.28 & 0.98 & 5.22 & 2.79 & 0.32 \\
\hline
\end{tabular}

Table.3 Effect of organic nutrient sources on viable bacterial count

\begin{tabular}{|c|c|c|c|c|c|c|c|c|c|c|c|c|c|c|c|c|}
\hline Treatments & $T_{1}$ & $\mathbf{T}_{2}$ & $T_{3}$ & $\mathbf{T}_{4}$ & $\mathbf{T}_{5}$ & $T_{6}$ & $\mathbf{T}_{7}$ & $\mathbf{T}_{8}$ & $\mathbf{T}_{9}$ & $T_{10}$ & $T_{11}$ & $T_{12}$ & $T_{13}$ & $T_{14}$ & $T_{15}$ & $T_{16}$ \\
\hline $\begin{array}{l}\text { Viable } \\
\text { bacterial } \\
\text { count } \times 10^{5} \\
\text { cfu/g soil }\end{array}$ & $127 . .33$ & 138.67 & 128.00 & 139.33 & 140.33 & 162.00 & 158.00 & 174.67 & 167.67 & 180.00 & 177.00 & 195.33 & 163.33 & 178.33 & 169.00 & 179.00 \\
\hline
\end{tabular}




\section{Viable bacterial count}

Data regarding viable bacterial count are presented in Table 3. A perusal of data revealed that among different treatments viable bacterial count were highest $\left(195.33 \times 10^{5}\right)$ in $\mathrm{M}_{2} \mathrm{~L}_{3}$ (vermicompost, Jeevamrit and Panchgavya) and lowest viable bacterial count $\left(127.33 \times 10^{5}\right)$ was recorded in $\mathrm{M}_{0} \mathrm{~L}_{0}$. The increase in viable microbial count might be due to incorporation of organic manures which provide a condusive environment for microbial proliferation due to increased organic $\mathrm{C}$, mineral $\mathrm{N}$ and total $\mathrm{N}$ content of soils.

It also may be due to the presence of macronutrients, essential micronutrients, many vitamins, essential amino acids, growth promoting factors like IAA, GA in Panchgavya which may provide nutrition to rhizosphere microorganisms and thus helped to increase their population (Natarajan, 2007). Present findings are in agreement with Kanan et al., (2005) and Rana et al., (2015). Shwetha (2007) reported similar result from combination of organic manure (vermicompost) and fermented organics (jeevamrit and panchgavya) in soyabean.

It can be concluded from the experiment, that combined application of vermicompost $5 \mathrm{t} / \mathrm{ha}+$ Jeevamrit - drenching @ 5\% + Panchgavya spray@3\% was found optimum for available NPK, viable bacterial count and NPK uptake. Therefore, vermicompost along with Jeevamrit and Panchgavya can be recommended for sustainable production of carrot and to nourish soil fertility under mid-hills condition of Himachal Pradesh.

\section{References}

Abbey, M., Nokes, M. and Netel, P.J. 1995. Dietary supplementation with orange and carrot juice in cigratte smokers lowers oxidation products in copper-oxidized low-density lipoproteins. Journal of American Dietetic Association. 95(6): 671-75.
Adeleye, E. O., Ayeni, L. S. and Ojeniyi, S. O. 2010. Effect of poultry manure on soil physico-chemical properties, leaf nutrients content and yield of yam (Dioscorea rotundata) on alfisol in south western Nigeria. Journal of American Science. 6(10): 871-78.

Arisha, H. M. and Bardisi, A. 1999. Effect of mineral fertilizers and organic fertilizers on growth, yield and quality of potato under sandy soil conditions. Journal of Agricultural Resource. 26: 391-05.

Bharadwaj, V. and Omanwar, P. K. 1994. Long term effects of continuous rotational cropping and fertilization on crop yields and soil properties - ii. Effects on EC, $\mathrm{pH}$, organic matter and available nutrients of soil. Journal of the Indian Society of Soil Science. 42(4): 387-392.

Gore, N. S. and Sreenivasa, M. N. 2011. Influence of liquid organic manures on growth, nutrient content and yield of tomato (Lycopersicon esculentum Mill.) in the sterilized soil. Karnatka Journal of Agricultural Sciences. 24(2): 153-57.

Jackson, M. L. 1973. Soil Chemical Analysis. Prentice Hall of India Private Limited, New Delhi, India. pp. 219-21.

Kannan, P., Saravanan, A., Krishnakumar, S. and Natarajan, S. K., 2005. Biological properties of soil as influenced by different organic manures. Journal of Agriculture and Biological Sciences. 1(2): 181-83.

Khan, G., Gupta, S. K. and Banerjee, S. K. 1984. Studies on the solubilisation of phosphorus in presence of different city wastes. Journal of the Indian Society of Soil Science. 29: 123-24.

Merwin, H. D. and Peach, M. 1951. Exchange ability of soil potassium in the sand, silt and clay fraction as influenced by the nature and complementary exchangeable cations. Soil Science American Proceedings. 15: 125-28.

Naeem, M., Iqbal, J. and Bakhsh, M. A. A. 2006. Comparative study of inorganic fertilizers and organic manures on yield and yield components of mungbean. 
Journal of Agriculture \& Social Sciences. 2(4): 227-39.

Natarajan, K. 2007. Panchgavya for plant. In: Proceedings of the National Conference on Glory of Gomatha, held at Sri Venkateswara Veterinary University, Tirupati, 1-3 December 2007, Tirupati, India. pp. 72-75.

Nehra, A. S., Hooda, I. S. and Singh, K. P. 2001. Effect of integrated nutrient management on growth and yield of wheat (Triticum aestivum L.). Indian Journal of Agronomy. 45: 112-17.

Olsen, S. R., Cole, C. V., Watenable, D. S. and Dean, L. A. 1954. Estimation of available phosphorus in soils by extraction with sodium bicarbonate. US Department of Agriculture Circular. 939p.

Panse, V. G. and Sukhatme, P. V. 2000. Statistical Methods for Agricultural Workers. Indian Council of Agricultural Research, New Delhi, India. pp. 157-65.

Prativa, K. C. and Bhattarai, B. P. 2011. Effect of integrated nutrient management on the growth, yield and soil nutrient status in tomato. Nepal Journal of Science and Technology. 12: 23-28.

Rana, M., Raverkar, K. P., Pareek, N., Chandra, R. and Singh, D. K. 2015. Impact of biodynamic preparations and panchgavya in organically managed cropping systems comprising legumes on soil biological health. Legume Research: An International Journal. 38(2): 219-28.

Rubatzky, V. E and Yamaguchi, M. 1999. World Vegetables: Principles, Production and Nutritive Values. $2^{\text {nd }}$ ed. Aspeen Publishers, Gaithersberg, Maryland. 420p.

Sharma, R. P., Datt, N. and Chander, G. 2009. Effect of vermicompost, farmyard manure and chemical fertilizers on yield, nutrient uptake and soil fertility in okra (Abelmoschus esculentus) - onion (Allium сера) sequence in wet temperate zone of Himachal Pradesh. Journal of the Indian Society of Soil Science. 57(3): 357-61.

Shwetha, B. N. 2007. Studies on nutrient management through organics in soybean - Wheat Cropping System. M.Sc. Thesis. Department of Agronomy, Dharwad University of Agricultural Sciences, Dharwad (India).

Singh, S. N., Rai, J. P., Singh, S. R., Goyal, S. K. and Singh, S. P. 2014. Effect of integrated use of organic manures and fertilizers on yield, nutrient uptake and soil fertility in onion on red soils of vindhyan region. Vegetable Science. 41: 150-54.

Subba Rao, N. S. 1999. Soil Microorganisms and Plant Growth. Oxford \& IBH publishing Co., New Delhi. 252p.

Subbiah, B. V. and Asija, G. L. 1956. A rapid procedure for the estimation of the available nitrogen in soils. Current Science. 25: 259-60.

Suklabaidya, A., Datta, M. and Kandpal, B. K. 2017. Response of organic sources and biofertilizer in soil fertility and yield of cauliflower in the foot hills of Tripura. International Journal of Agriculture Sciences. 9: 4874-75.

Suresh, K. D., Sneh, G., Krishna, K. K. and Mool, C. M. 2004. Microbial biomass carbon and microbial activities of soils receiving chemical fertilizers and organic amendments. Archives Agronomy Soil Science. 50: 641-647.

Wong, J. W. C., Ma, K. K., Fang, K. M. and Cheung, C. 1999. Utilization of manure compost for organic farming in Hong Kong. Bio-resource Technology. 67: 643.

\section{How to cite this article:}

Nitika, Kuldeep Singh Thakur and Devinder Kumar Mehta. 2018. Soil Nutrient Status, NPK Uptake and Viable Bacterial Count as Influenced by Different Organic Nutrient Sources in European Carrot. Int.J.Curr.Microbiol.App.Sci. 7(08): 1783-1789. doi: https://doi.org/10.20546/ijcmas.2018.708.204 